\title{
Analisis Tata Kelola Teknologi Informasi menggunakan Kerangka Kerja COBIT 5 pada AMIK JTC Semarang
}

\author{
Hadi Hilmawan ${ }^{1)}$, Oky Dwi Nurhayati ${ }^{2)}$, Ike Pertiwi Windasari ${ }^{2)}$ \\ Program Studi Sistem Komputer Fakultas Teknik Universitas Diponegoro \\ Jalan Prof. Sudharto, Tembalang, Semarang, Indonesia \\ hadihilmawan@gmail.com
}

\begin{abstract}
Informations technology has been important elements in an organisation but getting higher information technology implementation cost requires any company or organization to implement an effective operation of information technology. Information technology was expected to help organization in achieveing their business goals and providing not only financial profit but also non-financial profit. To achieve their business goals and ensuring process of information technology works effectively and efficiently, a continuously audit and evaluation of our IT process need to introduced in organization. It will help organization aligning their business process with IT process.

One of IT governance framework is COBIT 5. COBIT 5 is a comprehensive framewok that helps organizations to create optimal value from IT by maintaining a balance between realizing benefits and optimizing risk levels and resources use. COBIT 5 enables information and related technology to be governed and managed in a holistic manner for the whole organizations, taking full end to end business and functional area of responsibility, considering the IT-related intererst of internal and external stakeholders.
\end{abstract}

Keywords : information technology, governance, COBIT 5

\section{PENDAHULUAN}

$\mathrm{P}$ ERKEMBANGAN teknologi informasi yang dipandang saat ini sebagai media pendukung korganisasi dalam mencapai tujuan bisnis membuat teknologi informasi diharuskan untuk dapat berbaur dalam setiap proses bisnis dari organisasi. Diharapkan adanya keselarasan antara proses bisnis dan proses pada teknologi informasi sehingga dapa saling mendukung dalam mencapai tujuan organisasi. Pemanfaatan teknologi informasi tidak hanya dimanfaatkan dalam organisasi yang berorientasi profit namun juga dimanfaatkan dalam organisasi non-profit. [3][10]

Kesuksesan pemanfaatan teknologi informasi yang dilakukan oleh banyak perusahaan dalam mendukung proses bisnis telah menginsipirasi para pimpinan perguruan tinggi dalam menerapakan proses teknologi informasi yang yang efektif dengan meningkatkan kemampuan kompetitif dan mentransformasikan layanan, proses kerja dan hubungan antar komunitas civitas akedemik, peneliti dan berbagai level kepentingan dan stakeholders. Karena itu penerapan TI perlu disusun secara hati-hati melalui kebijakan tata kelola (IT Governance). Hal ini dilakukan untuk meningkatkan peran TI dalam pencapaian kinerja, peningkatan aset organisasi, mentransformasikan layanan, pasar, proses kerja, hubungan bisnis dan meningkatkan keunggulan kompetitif organisasi.[12]

AMIK JTC Semarang adalah sebuah organisasi pendidikan tinggi yang berfokus dalam pengembangan tenaga kerja profesional dalam bidang teknologi. Dalam menjalankan proses bisnisnya AMIK JTC Semarang memanfaatkan teknologi informasi dalam mencapai tujuannya. Namun pemanfaatan teknologi informasi masih belum dikelola dengan baik, keselarasan dalam proses teknologi informasi dan proses bisnis yang masih belum dievaluasi. Maka dari itu dibutuhkan audit atau evaluasi untuk memastikan bahwa kebutuhan, kondisi, dan pilihan stakeholder sesuai dengan tujuan organisasi menetapkan priorotas dalam pengambilan keputuasan, dan memantau kinerja berdasarkan tujuan dan arahan. Diharapakan dengan adanya audit dan evaluasi terkait proses tata kelola teknologi

COBIT (Control Objective for Information and related Technology). COBIT merupakan suatu kerangka kerja atau panduan best practices manajemen dan teknologi informasi. Kerangka COBIT yang digunakan adalah COBIT 5 yang merupakan kerangka COBIT paling baru. Keunggulan COBIT 5 yang mengemukakan bahwa mereka telah mengidentifikasi beberapa tantangan yang dihadapi COBIT Maturity Model dan menawarkan model penelitian alternatif. Mereka telah mendemonstrasikan bahwa ternyata alternatif model penilaian berdasarkan ISO/IEC 15504 yaitu COBIT 5 memiliki kriteria penelitian yang lebih akurat, konsisten, dan obyektif. Oleh karena itu mereka menyatakan bahwa model penelitian berdasarkan ISO 15504 lebih superior yang lebih dikenal sebagai Model Capability Level pada COBIT 4.1.[11]

\section{DASAR TEORI}

A. Tata Kelola Teknologi Informasi

Tata Kelola Teknologi Informasi didefinisikan sebagai aktifitas menetapkan hak pengambilan keputusan dan kerangka kerja yang dapat dipertanggungjawabkan (accountability framework). Tata Kelola Teknologi Informasi meliputi budaya-budaya, pengorganisasian, peraturan dan praktik yang menghasilkan sistem pengawasan dan transparansi dalam pemanfaatan IT. Tata Kelola Teknologi Informasi adalah sebagian dari aktivitas Coorporate Governace yang lebih besar tetapi dengan fokus tersendiri. Keuntungan dalam penerapan IT risk management yang baik, 
pengawasan dan mengurangi beban karena kegagalan dari penerapan IT tetapi juga dapat menimbulkan kepercayaan, kekompakkan, dan percaya diri dalam penggunaan sumber daya IT dan juga terhadap layanan IT.[9]

Tata Kelola Teknologi Informasi menerangkan siapa yang membuat keputusan dan bagaiamana keputusan tersebut dibuat (dalam IT). Tata Kelola Teknologi Informasi adalah sebuah proses dimana organisasi menyelaraskan IT actions dengan visi dan misi yang ingin dicapai organisasi. Hal ini dicapai dengan mengambil keputusan tepat (siapa memutuskan apa) dan menerapkan sebuah framework yang akuntabilitas (siapa bertanggung jawab tentang apa) sehingga setiap keputusan yang diambil dapat mengembangkan penggunaan IT di organisasi tersebut.[4]

\section{B. COBIT 5}

Pada COBIT 5 yang merupakan framework terbaru yang dirilis COBIT pada 2012 yang dilengkapi beberapa fitur tambahan. Pada COBIT 5 dilengkapi oleh 5 prinsip dan 7 enablers yang diberikkan untuk melengkapi fitur yang sebelumnya ada pada versi terdahulunya COBIT 4.1. Pada COBIT diperkenalkan unsur VAL IT, Val IT adalah sebuah kerangka tata kelola yang meliputi prinsip penerimaan dari proses pendukung yang berhubungan dengan evaluasi dan seleksi yang memungkinkan investasi TI dalam bisnis, melakukan realisasi dari manfaat, dan memberikkan nilai dari investasi tersebut. Terdapat juga pemisahan jelas antara proses tata kelola dan proses manajemen yang terdapat pada COBIT 5. Sehingga bisa disimpulkan COBIT 5 dibangun berdasarkan pengembangan dari COBIT 4.1 dengan mengintegrasikan Val IT dan Risk IT dari ISACA, ITIL, dan standar-standar yang relevan dari ISO. [7] [8]

Menurut COBIT, keputusan bisnis yang baik harus didasarkan pada pengetahuan yang berasal dari informasi yang relevan, komprehensif dan tepat waktu, yang dapat dihasilkan jika informasi memenuhi kriteria informasi. Kerangka kerja COBIT 5, yang terdiri atas 5 prinsip utama dan dilengkapi dengan 7 enabler. COBIT 5 menyelarasakan antara lima prinsip yang memungkinkan organisasi enterprise untuk membangun sebuah framework tata kelola dan manajemen yang efektif berdasarkan pendekatan holistik dari tujuh enabler yang disediakan sehingga dapat mengoptimalisasikan investasi bidang teknologi dan informasi sekaligus memberikkan keuntungan kepada stakeholder. Pada gambar 1 kita bisa melihat lima prinsip COBIT 5.[1][2][4]

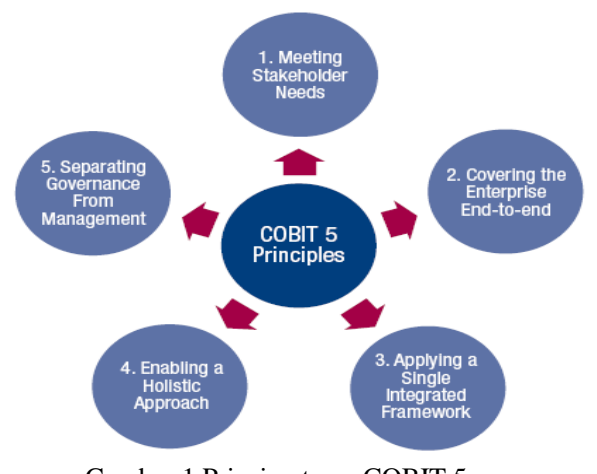

Gambar 1 Prinsip utama COBIT 5
Pada gambar 2 kita bisa melihat ketujuh enablers yang ada pada COBIT 5.

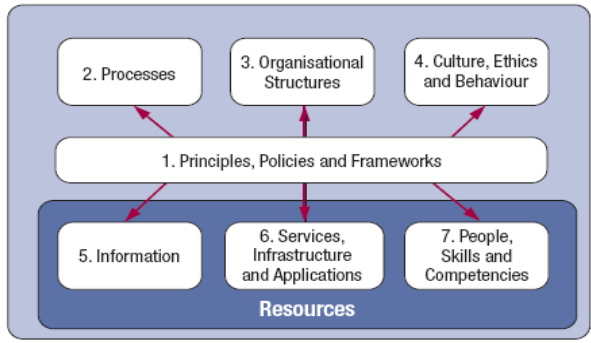

Gambar 2 Tujuh enblers COBIT 5

Untuk dapat memahami kerangka kerja COBIT 5 perlu diketahui apa saja yang menjadi faktor penggerak pada COBIT 5 apa saja proses yang terdapat didalamnya dan bagaimana indikator penilaian terhadap process assessments model di COBIT 5. Aktivitas teknologi informasi pada COBIT 5 didefinisikan kedua dimensi bisnis utama yaitu governance dan management.[7][8]

a. Governance - Terdiri atas lima domain dalam proses evaluate, direct, and monitor (EDM).

b. Management - Terdiri atas 4 domain utama yang bertanggung jawab pada area Plan, Build, Run, and Monitor (PBRM). Domain-domain pada area manajemen COBIT 5 merupakan perkembangan dari versi terdahulu dengan perkembangan yang dapat mencakup area yang lebih luas.

Bisa disimpulkan bahwa COBIT 5 memiliki 2 area kerja utama yang dipisahkan antara management dan governance. Terdapat 5 domain utama dalam 2 area kerja COBIT 5 yaitu :

a. Governance of Enterprise IT

i. Evaluate, Direct and Monitor (EDM)

b. Management of Enterprise IT

ii. Align, Plan, and Organise (APO)

iii. Build, Acquire, and Implement (BAI)

iv. Deliver, Service, and Support (DSS)

v. Monitor,Evaluate, and Assess (MEA)

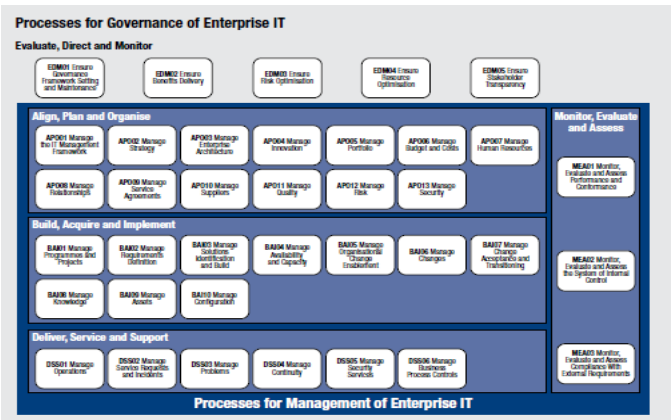

Gambar 3 Area utama Management dan Governance pada COBIT 5

Pada gambar 3 menunjukkan area utama pembagian proses yang bagi atas 2 area yaitu management dan governance. 


\section{Proses Capability Level}

Pemahaman terhadap status sistem teknologi informasi, diperlukan bagi organisasi, agar dapat memutuskan tingkat manajemen dan kontrol yang harus diberikan, oleh karena itu perusahaan perlu mengetahui apa yang harus diukur dan bagaimana pengukuran tersebut dilakukan, sehingga diperlukan status tingkat kinerjanya. Pada versi COBIT terdahulu kita mengenal adanya Maturity level namun pada COBIT 5 kita mengenal dengan nama Capability level. Model pengukuran ini didasarkan pada standar ISO/IEC 15504 Software Engineering-Process Assessment Standard. Terdapat 6 level proses tingkatan yang harus dicapai pada setiap proses, berikut ini adalah 6 Capability level yang terdapat pada COBIT 5 [5][8]:

a. Level 0 (Incomplete), tidak dilaksanakan atau sedikit/tidak ada bukti sistematis atas tujuan proses.

b. Level 1 (Performed), telah mencapai tujuan proses.

c. Level 2 (Managed), diimplementasikan dalam model yang terkelola (direncanakan, dimonitor, dan disesuaikan) dengan produk kerja yang tepat, dikendalikan, dan dipelihara.

d. Level 3 (Established), terimplementasi sesuai standar yang ada.

e. Level 4 (Predictable), beroperasi sesuai batas yang ditentukan untuk mencapai hasil proses.

f. Level 5 (Optimized), terus ditingkatkan untuk memenuhi kodisi terkini yang relevan dan diarahkan pada tujuan bisnis.

\section{METODE DAN MAPPING}

Penelitian ini bertujuan untuk mengidentifikasi bagaimana proses TI yang berlangsung di AMIK JTC apakah sudah berjalan dan terkelola dengan baik dan juga dilakukan identifikasi terhadap kondisi yang diharapkan di masa mendatang. Identifikasi proses TI yang sedang berlangsung dilakukan dengan melakukan observasi, wawancara, kuisoner, dan studi lapangan. Sedangkan identifikasi kondisi yang diharapkan di masa mendatang dilakkan dengan wawancara kepada para pengambil kebijakan dan pembacaan dokumen Rencana Strategis AMIK tahun 2010-2014.

Data yang sudah didapat akan dipetakan kedalam Enterprises Goal dan IT-related Goals COBIT 5 sampai didapat proses mana saja yang menjadi fokus di AMIK JTC Semarang untuk dievaluasi dan ditingkatkan kinerjanya. Proses tersebut merepresentasikan proses yang sesuai dengan budaya kerja pada divisi TI AMIK JTC Semarang dengan peningkatan performa pada proses tersebut diharapakan AMIK JTC dapat lebih mudah untuk mencapai tujuan bisnis denga dukung TI yang efisien dan efektif.

Pada gambar 4 menunjukkan flowchart tahapan penelitian ini:

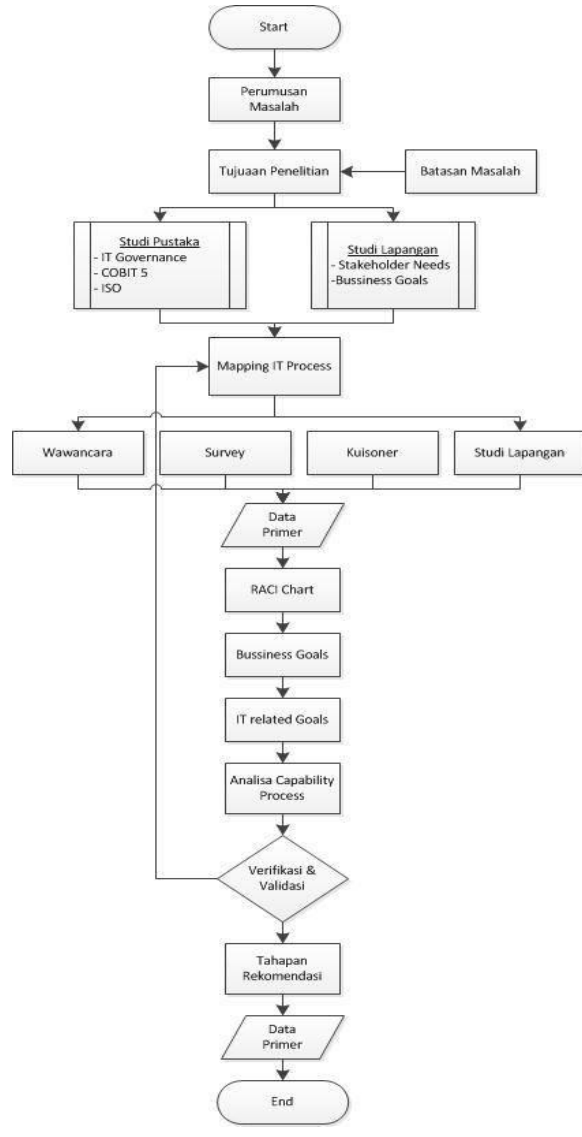

Gambar 4 Flowchart penelitian

Pada tabel 1 menunjukkan pemetaan dari Rencana strategis AMIK menuju Enterprise Goals

Tabel 1 Pemetaan menuju Enterprise Goals

\begin{tabular}{|c|c|c|c|c|c|c|}
\hline \multirow{2}{*}{ Kode EnG } & \multicolumn{7}{|c|}{ Strategi Bisnis } \\
\hline & R1 & R2 & R3 & R4 & R5 & R6 \\
\hline EG01 & $\sqrt{ }$ & $\sqrt{ }$ & $\sqrt{ }$ & $\sqrt{ }$ & $\sqrt{ }$ & $\sqrt{ }$ \\
\hline EG02 & $\sqrt{ }$ & & $\sqrt{ }$ & $\sqrt{ }$ & & $\sqrt{ }$ \\
\hline EG03 & & $\sqrt{ }$ & $\sqrt{ }$ & & & \\
\hline EG04 & & & & $\sqrt{ }$ & $\sqrt{ }$ & \\
\hline EG05 & & & & $\sqrt{ }$ & $\sqrt{ }$ & \\
\hline EG06 & $\sqrt{ }$ & $\sqrt{ }$ & $\sqrt{ }$ & & $\sqrt{ }$ & \\
\hline EG07 & & $\sqrt{ }$ & $\sqrt{ }$ & & & \\
\hline EG08 & $\sqrt{ }$ & $\sqrt{ }$ & $\sqrt{ }$ & & & \\
\hline EG09 & & $\sqrt{ }$ & & & $\sqrt{ }$ & \\
\hline EG10 & & & & $\sqrt{ }$ & $\sqrt{ }$ & \\
\hline EG11 & $\sqrt{ }$ & & & & $\sqrt{ }$ & $\sqrt{ }$ \\
\hline EG12 & & & $\sqrt{ }$ & $\sqrt{ }$ & \\
\hline EG13 & & & & $\sqrt{ }$ & $\sqrt{ }$ & \\
\hline EG14 & $\sqrt{ }$ & $\sqrt{ }$ & $\sqrt{ }$ & & $\sqrt{ }$ & \\
\hline EG15 & & & & $\sqrt{ }$ & $\sqrt{ }$ & \\
\hline EG16 & $\sqrt{ }$ & $\sqrt{ }$ & & & & $\sqrt{ }$ \\
\hline EG17 & $\sqrt{ }$ & $\sqrt{ }$ & & & & $\sqrt{ }$ \\
\hline
\end{tabular}

Dari hasil pemetaan diambil 8 poin Enterprise goals yaitu EG 01, EG 02, EG 06, EG 08, EG 11, EG 14, EG 16, dan EG 17 yang akan dibawa pada pemetaan IT-related Goals.

Pada tabel 2 menunjukkan pemetaan dari Enterprise Goals menuju IT related Goals. 
Tabel 2 Pemetaan menuju IT related Goals

\begin{tabular}{|c|c|c|c|c|c|c|c|c|}
\hline \multirow[b]{2}{*}{ Kode ITr } & \multicolumn{8}{|c|}{ Enterprise Goals } \\
\hline & 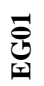 & $\underset{\mho}{\stackrel{\vartheta}{S}}$ & $\underset{ఝ}{Ð}$ & 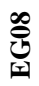 & $\underset{b}{\exists}$ & $\underset{\Xi}{ \pm}$ & $\underset{0}{0}$ & $\underset{0}{0}$ \\
\hline ITr01 & $\bar{P}$ & $\mathrm{P}$ & $\mathrm{P}$ & $\mathrm{P}$ & & & & \\
\hline \multicolumn{9}{|l|}{ ITr02 } \\
\hline ITr03 & $\mathrm{P}$ & & & & & & & \\
\hline \multicolumn{9}{|l|}{ ITr04 } \\
\hline ITr05 & $\mathrm{P}$ & $\mathrm{P}$ & & & & & & \\
\hline \multicolumn{9}{|l|}{ ITr06 } \\
\hline ITr07 & $\mathrm{P}$ & $\mathrm{P}$ & $\mathrm{P}$ & $\mathrm{P}$ & $\mathrm{P}$ & & & \\
\hline ITr08 & & & & & $\mathrm{P}$ & $\mathrm{P}$ & & \\
\hline ITr09 & & $\mathrm{P}$ & & $\mathrm{P}$ & $\mathrm{P}$ & & & $\mathrm{P}$ \\
\hline \multicolumn{9}{|l|}{ ITr10 } \\
\hline ITr11 & $\mathrm{P}$ & & & & & & & \\
\hline ITr12 & & $\mathrm{P}$ & & & $\mathrm{P}$ & & & \\
\hline ITr13 & $\mathrm{P}$ & & & & & & & \\
\hline \multicolumn{9}{|l|}{ ITr14 } \\
\hline \multicolumn{9}{|l|}{ ITr15 } \\
\hline ITr16 & & & & & & $\mathrm{P}$ & $\mathrm{P}$ & \\
\hline ITr17 & & $\mathrm{P}$ & & $\mathrm{P}$ & & & & \\
\hline
\end{tabular}

Dari hasil pemetaan diambil 11 poin IT related Goals yan mendapat poin primary terbanyak yaitu ITr $01, \mathrm{ITr} 03, \mathrm{ITr}$ 05, ITr 07, ITr 08, ITr 09, ITr 11, ITr 12, ITr 13, ITr 16, dan ITr 17 yang akan dibawa pada pemetaan IT processs.

Pada tabel 3 menunjukkan pemetaan dari IT related Goals menuju IT process. Nilai $\mathrm{P}$ meurupakan poin Primary yang dianggap penting dan nilai $\mathrm{S}$ merupakan nilai Secondary yang dianggap sebagai poin pendukung.

Tabel 3 Pemetaan menuju IT related Goals

\begin{tabular}{|c|c|c|c|}
\hline Kode IT Process & Nilai P & Nilai S & Nilai Identifikasi \\
\hline EDM 01 & 3 & 7 & $\mathrm{P}$ \\
\hline EDM 02 & 4 & 6 & $\mathrm{P}$ \\
\hline EDM 04 & 3 & 7 & $\mathrm{P}$ \\
\hline APO 01 & 5 & 4 & $\mathrm{P}$ \\
\hline APO 02 & 3 & 8 & $\mathrm{P}$ \\
\hline APO 03 & 3 & 6 & $\mathrm{P}$ \\
\hline APO 04 & 5 & 1 & $\mathrm{P}$ \\
\hline APO 05 & 3 & 6 & $\mathrm{P}$ \\
\hline APO 07 & 5 & 3 & $\mathrm{P}$ \\
\hline APO 08 & 4 & 6 & $\mathrm{P}$ \\
\hline APO 10 & 2 & 5 & $\mathrm{P}$ \\
\hline APO 11 & 3 & 6 & $\mathrm{P}$ \\
\hline BAI 01 & 3 & 5 & $\mathrm{P}$ \\
\hline BAI 02 & 3 & 7 & $\mathrm{P}$ \\
\hline BAI 03 & 1 & 7 & $\mathrm{P}$ \\
\hline BAI 04 & 2 & 5 & $\mathrm{P}$ \\
\hline BAI 05 & 3 & 7 & $\mathrm{P}$ \\
\hline BAI 07 & 2 & 5 & $\mathrm{P}$ \\
\hline BAI 08 & 2 & 6 & $\mathrm{P}$ \\
\hline DSS 01 & 2 & 5 & \\
\hline & & & 5 \\
\hline
\end{tabular}

Dari hasil pemetaan diambil 20 proses dari 37 proses yang ada pada COBIT 5 untuk dilakukan assessment nilai capability level pada masing-masing proses. [6]

\section{ANALISIS DAN REKOMENDASI}

\section{A. Analisis}

Tahapan ini merupakan tahapan perhitugan nilai kapabilitas setiap proses. Penilaian kapabilitas didasarkan oleh standar penilaian yang pada COBIT 5 assessment model.
Penilaian capability level terbagi atas 6 level dan 4 kriteria pada masing-masing level. Setiap proses dinilai apakah akivitas-aktivitas yang mewakili setiap proses tersebut sudah berjalan dengan baik dan mencapai tujuan yang diinginkan. Berikut ini adalah salah satu contoh penilian kapabilitas pada proses EDM 01 (Ensure Governance Framework and Setting Maintenance) ditujukkan pada tabel 4 [6]:

Tabel 4 Pemetaan kondisi reality proses EDM 01

EDM 01 Ensure Governance Framework and Setting Maintenance

\begin{tabular}{|c|c|c|c|}
\hline Governance Practice & Output & Ada & Skor \\
\hline \multirow{2}{*}{$\begin{array}{c}\text { EDM 01.01 Evaluate the } \\
\text { governance system }\end{array}$} & $\begin{array}{c}\text { Prinsip-prinsip tata kelola } \\
\text { organisasi }\end{array}$ & $\sqrt{ }$ & \\
\cline { 2 - 3 } & Model Pengambilan Keputusan & - & $66.7 \%$ \\
\cline { 2 - 3 } & Level Otoritas & $\sqrt{ }$ & \\
\hline \multirow{2}{*}{$\begin{array}{c}\text { EDM 01.02 Direct the } \\
\text { governance system }\end{array}$} & $\begin{array}{c}\text { Pengkomunikasian tata kelola } \\
\text { perusahaan }\end{array}$ & $\sqrt{ }$ & \multirow{2}{*}{$50 \%$} \\
\cline { 2 - 3 } & $\begin{array}{c}\text { Pendekatan menggunakan sistem } \\
\text { reward }\end{array}$ & - & \\
\hline $\begin{array}{c}\text { EDM 01.03 Monitor the } \\
\text { governance system }\end{array}$ & $\begin{array}{c}\text { Masukan terhadap keefektifan } \\
\text { tata kelola dan performa }\end{array}$ & $\sqrt{ }$ & $100 \%$ \\
\hline \multicolumn{2}{|c|}{ Nilai Rata-rata Proses EDM 01 } & $72.3 \%$ \\
\hline
\end{tabular}

Dapat dilihat pada tabel EDM 01.01 terdapat 2 dari 3 aktivitas yang mendapai poin centang $(\sqrt{ })$ yang menandakan bahwa aktivitas tersebut dapat ditemui prosesnya dan terdapat bukti pendukung bahwa aktivitas tersebut berjalan. Nilai tersebut diambil dan kemudian dirata-rata dengan aktivitas lainnya pada proses EDM 01 sehingga mendapatkan nilai $72.3 \%$ yang berada pada L (Largely Achieved) pada level 1. Nilai kapabilitas proses pada proses ini akan dibandingkan dengan level expectation yang diharapkan dari proses EDM 01. Tabel 5 menunjukan level expectation yang diharapkan dari proses EDM 01 berdasarkan wawancara dan pembacaan dokumen renstra AMIK JTC Semarang.

Tabel 5 Pemetaan level expectation proses EDM 01

EDM 01 Ensure Governance Framework and Setting Maintenance

\begin{tabular}{|c|c|c|c|c|}
\hline Governance Practice & Output & $\mathrm{P}$ & $\mathrm{S}$ \\
\hline \multirow{3}{*}{$\begin{array}{c}\text { EDM 01.01 Evaluate the } \\
\text { governance system }\end{array}$} & $\begin{array}{c}\text { Prinsip-prinsip tata kelola } \\
\text { organisasi }\end{array}$ & & $\sqrt{ }$ & \\
\cline { 2 - 6 } & Model Pengambilan Keputusan & & $\sqrt{ }$ & \\
\hline & Level Otoritas & & $\sqrt{ }$ & \\
\hline \multirow{2}{*}{$\begin{array}{c}\text { EDM } 01.02 \text { Direct the } \\
\text { governance system }\end{array}$} & $\begin{array}{c}\text { Pengkomunikasian tata kelola } \\
\text { perusahaan }\end{array}$ & & $\sqrt{ }$ \\
\cline { 2 - 6 } & $\begin{array}{c}\text { Pendekatan menggunakan sistem } \\
\text { reward }\end{array}$ & & $\sqrt{ }$ \\
\hline $\begin{array}{c}\text { EDM } 01.03 \text { Monitor the } \\
\text { governance system }\end{array}$ & $\begin{array}{c}\text { Masukan terhadap keefektifan tata } \\
\text { kelola dan performa }\end{array}$ & $\sqrt{ }$ & \\
\hline
\end{tabular}

Dapat dilihat pada tabel pemetaan diatas, level expectation proses EDM 01 berada pada poin M (Manage) yang bisa diartikan berada pada level 2. Diharapkan proses pada level 2 proses tersebut sudah diimplementasikan dalam model yang terkelola (direncanakan, dimonitor, dan disesuaikan) dengan produk kerja yang tepat, dikendalikan, dan dipelihara.

Proses EDM 01 ini merupakan salah satu dari 20 proses yang diaudit dan dievaluasi. Rekapitulasi antara kondisi reality dan level expectation seluruh proses ditunjukkan pada tabel 6 dibawah ini disertai juga perbandingan gap antara proses yang di audit: 
Tabel 5 Analisis Gap proses COBIT 5

\begin{tabular}{|c|c|c|c|}
\hline Activity & Expected & Reality & Gap \\
\hline EDM 01 & Level 2 & Level 1 & 1 \\
\hline EDM 02 & Level 2 & Level 1 & 1 \\
\hline EDM 04 & Level 2 & Level 1 & 1 \\
\hline APO 01 & Level 2 & Level 1 & 1 \\
\hline APO 02 & Level 3 & Level 1 & 2 \\
\hline APO 03 & Level 3 & Level 1 & 2 \\
\hline APO 04 & Level 2 & Level 1 & 1 \\
\hline APO 05 & Level 2 & Level 1 & 1 \\
\hline APO 07 & Level 3 & Level 1 & 2 \\
\hline APO 08 & Level 2 & Level 1 & 1 \\
\hline APO 10 & Level 3 & Level 1 & 2 \\
\hline APO 11 & Level 2 & Level 1 & 1 \\
\hline BAI 01 & Level 2 & Level 1 & 1 \\
\hline BAI 02 & Level 2 & Level 1 & 1 \\
\hline BAI 03 & Level 3 & Level 1 & 2 \\
\hline BAI 04 & Level 2 & Level 1 & 1 \\
\hline BAI 05 & Level 2 & Level 1 & 1 \\
\hline BAI 07 & Level 2 & Level 1 & 1 \\
\hline BAI 08 & Level 2 & Level 1 & 1 \\
\hline DSS 01 & Level 2 & Level 1 & 1 \\
\hline
\end{tabular}

Penjelasan dari tabel 4.61 menunjukkan rata-proses pada AMIK berada pada level 1 (Performed Process) level ini dartikan bahwa setiap proses sudah didefenisikan dan mencapai tujuannya. Terdapat bukti bahwa praktik-praktik dasar sudah dilakukan dan menghasilkan proses TI yang membantu AMIK JTC dalam mencapati tujuan bisnis organisasi. Dari hasil yang ditunjukkan oleh tabel diatas akan diberikkan rekomendasi untuk mencapai level yang diharapkan. Rekomendasi akan dibagi pada masing-masing domain bagaimana atau langkah apa saja yang harus diterpakan untuk mencapai level yang diinginkan. Perhitungan rata-rata capability level AMIK diambil dengan rumus seperti dibawah ini:

\section{Capability Level :}

$\frac{(0 * X 0)+\left(1 * \sum X 1\right)+\left(2 * \sum X 2\right)+\left(3 * \sum X 3\right)+\left(4 * \sum X 4\right)+\left(5 * \sum X 4\right)}{Y}$ Y

\section{Keterangan :}

\section{$\mathrm{X} 0, \mathrm{X} 1, \mathrm{X} 2, \mathrm{X} 3, \mathrm{X} 4$ = Level yang ada}

$\mathrm{Y}=$ Jumlah Level yang dinilai

Sehingga didapat nilai Capabilty Level pada AMIK JTC Semarang pada level 1,00 dengan Level Expectation rata-rata pada level 2,30 didapat gap sebesar 1,30 poin lagi untuk mencapai level yang diharapkan. Pada pembahasan selanjutnya akan dibahas rekomendasi dan saran apa yang dapat diterapkan dan diimplementasi di AMIK JTC Semarang untuk mencapai nilai tata kelola TI yang diharapkan.

\section{B. Rekomendasi}

Rekomendasi yang disampaikan terbagi pada masingmasing level dikarenakan kriteria pencapaian setiap level berbeda-beda. Pihak AMIK JTC diharapkan untuk memenuhi dulu persyaratan pada level 1 yaitu mendapat nilai F (Fully Achieved) pada seluruh aktivitias disetiap proses baru dilanjutkan dalam melakukan perbaikan untuk mencapai level 2 dan level 3. Berikut ini adalah beberapa poin rekomendasi untuk mengatasi gap capability level pada level 1 di AMIK JTC Semarang:

a. Pembuatan model pengambilan keputusan terkait TI, model pengambilan keputusan ini sangat penting agar diketahui individu yang bertanggung jawab pada setiap pengimplementasian proyek. Dan didapat sebuah transparansi dalam pengambilan keputusan tidak ada keputusan penting dibuat sepihak.

b. Mengimplemetnasikan pendekatan review stage gate. Review stage gate ini merupakan sebuah proses yang dapat mengevaluasi dan menilai kesesuian dalam tata kelola TI dan sekaligus memberikkan panduan tentang factor-faktor itis terhadap investasi yang sudah dilakukakan apakah investasi tersebut disetujui dan memenuhi persyaratan.

c. Dokumentasi pengalokasian sumber daya yang baik. Pengalokasian sumber daya (TI, teknologi dan manusia) diharapkan mendetail dengan spesifikasi dan kemampuan. Sehingga dapat mempermudah pihak AMIK dalam melakuan pemetaan kondisi sekarang.

d.Pedoman terkait pengamanan data, kontrol, dan penjaminan integirtas data.

e.Pemetaan terkait kemampuan TI sekarang, kondisi lingkungan TI, kemampuan, dan layanan yang dapat dibandingkan dengan kondisi yang diinginkan.

f. Pembuatan Enterprise Architecture dengan framework sudah terstandarisasi contohnya dengan framework Zachman.

g. Bukti inovasi di follow up oleh pihak manajemen sehingga terjadi validasi data, dan dapat menjamin keefektifan implementasi dari proses tersebut.

h. Pengenalan model ROI milestones, yang dapat memantau perkembangan pelaksanaan portofolio yang dinilai pada setiap tahapan.

i. Pengelompokkan inventaris terkait sumber daya manusia pada divisi TI, sehingga dapat dibedakan kemampuan dan komptensi masing-masing individu.

j. Membahas model pengambilan keputusan yang baik dan dapat mengakomodir tujuan dan proses bisnis pada AMIK.

k. Membahas dan merumuskan suatu sistem penjaminan mutu terkait layanan TI di AMIK.

1. Pendekatan business case dan business chapter sebelum memulai program sebaiknya mulai diimplementasi.

m. Pendekatan business case dan business chapter sebelum memulai program sebaiknya mulai diimplementasi.

n. Identifikasi dan merumuskan suatu mekanisme yang dapat mengukur bagaimana ketersediaan, performa, dan kapasitas layanan TI yang sesuai dengan budaya AMIK JTC.

o. Perlunya penerapan penilaian yang dilengkapi KPI (Key Performance Indicator) pada operasional layanan TI dan pengukuran kinerja SDM divisi TI.

p.Perlu diperhatikan dan disusun mengenai aspek migrasi, konversi, dan backup dari data dan informasi pada saat terjadi nya perubahan pada sistem ataupun pada operasional layanan TI. 
q. Pembuatan dan pengelompokkan terhadap database informasi dan pengetahuan sehingga dapat memudahkan pelanggan dalam pengaksesan informasi.

r. Perlu diterapkannya sistem incident tickets dimana para user atau pelanggan dapat memberikkan keluhan langsug berupa laporan ke admin mengenai permasalahan pada jaringan.

Berikut ini adalah beberapa poin rekomendasi untuk mengatasi gap capability level menuju level 2 di AMIK JTC Semarang:

\section{Performance Management Level 2}

a. Identifikasi obyektif performa dari setiap proses.

b. Perencanaan dan pemantauan performa dari proses.

c. Performa dari proses disesuaikan dengan perencanaan.

d. Terdapat penugasan pada setiap implementasi proses.

e. Penyediaan sumber daya dan informasi pendukung pada setiap proses.

f. Menyediakan mendia komunikasi terhadap pihak-pihak yang terlibat.

\section{Work Product Management Level 2}

a. Penerapan dan identifikasi kebutuhan.

b. Adanya dokumentasi dan kontrol.

c. Review terhadap kesuaian hasil kerja.

Berikut ini adalah beberapa poin rekomendasi untuk mengatasi gap capability level menuju level 2 di AMIK JTC Semarang:

a. Pembuatan renstra TI (IT masterplan) divisi TI.

b. Pembuatan mekanisme penilaian kapabilitas dan analisis gap terkait layanan dan proses kritikal.

c. Penyempurnaan portofolio investasi TI.

d.Penyempurnaan Enterprises Architecture dengan menggunak standar yang ada sekaligus melibatkan pihak ketiga dalam pembuatan EA.

e. Pembuatan Human Resources System (HR System) yang dapat memetaakan seluruh sumber daya manusia berdasarkan kemampuan, kompetensi, dan pengalaman yang ada.

f. Pembuatan Business and IT planning cycles dan Business IT planning plans.

g. Pendokumentasian dalam hal perjanjian kerjasama/pembelian, dokumen pengalamatan resiko supplier yang ditunjuk ke dalam sebuah procurement system (sistem pembelian).

h. Diterapkan mekanisme tender yang sesuai dalam pemilihan supplier.

i. Pembuatan dan penerapan model SDLC (System DevelopmentLife Cycle) yang menjadi standar dalam pengimplemasian suatu aplikasi atau proyek di AMIK JTC.

\section{KESIMPULAN DAN SARAN}

\section{A. Kesimpulan}

Berdasarkan hasil analisis dan evaluasi tata kelola teknologi informasi AMIK JTC Semarang menggunakan framework COBIT 5, maka dapat disimpulkan hal-hal sebagai berikut:

1. Berdasarkan pemetaan antara tujuan bisnis dan Rencana Strategis AMIK tahun 2010-2014 terdapat 20 dari 37 proses yang menjadi fokus utama penelitian yang terbagi atas 4 domain.

2. Berdasarkan analisis tata kelola TI di AMIK JTC Semarang didapat nilai capability level pada level 1 (Performed Process) yang menyatakan bahwa setiap proses TI di AMIK sudah berjalan dengan baik dan sudah mendapat tujuan yang ingin dicapai. Sedangkan pada level expectation yang diharapkan ada pada level 2 (Managed Process) dan terdapat 6 proses yang diharapkan dapat mencapai level 3.

3. Agar dapat mecapai level yang ditarget maka disusunlah beberapa rekomendasi yang disesuaikan berdasarkan budaya kerja dan standar yang ada

\section{B. Saran}

1. Disarankan bagi peneliti untuk proses pengidentifikasi dokumen-dokumen yang dibutuhkan hendaknya dibahas lebih mendetail dengan diskusi dengan pihak-pihak terkait sehingga dapat lebih mengerti proses kerja yang berjalan di AMIK JTC.

2. Disarankan untuk poin rekomendasi hendaknya disertai dengan contoh terkait pengimplementasian yang sudah baik sehingga pihak AMIK dapat mengetahui gambaran dalam melakukan perbaikan proses-proses yang masih mendapat nilai dibawah keinginan..

\section{DAFTAR PUSTAKA}

[1] IT Governance Institute. COBIT 4.0. 2005

[2] IT Governance Institute, Enterprise Value : Governance of IT Investment. The Val IT Framework 2.0 Extract. 2008

[3] Gondodiyoto, Sanyoto. 2007. Audit Sistem Informasi + Pendekatan COBIT. Jakarta: Mitra Wacana Media.

[4] IT Governance Institute (ITGI). 2007. COBIT 4.1: Framework, Control Objectives, Management Guidelines, Maturity Models. Rolling Meadow. USA

[5] Elvira, Marina. 2013. Perancangan IT Governance untuke Telkom University dengan menggunakan Tool COBIT 5. Skripsi Fakultas Rekayasa Industri Institut Teknologi Telkom Bandung.

[6] IT Governance Institute. COBIT 5.0. 2012. Enabling Process

[7] IT Governance Institute. COBIT 5.0. 2012. Introduction to COBIT 5.

[8] IT Governance Institute. COBIT 5.0. 2012. Main Framework Version 2.

[9] Weber, Ron. 2000. Information Sistem Controls and Audit. New Jersey: Prentice Hall, Inc.

[10] Weill, Peter, \& Jeanne W, Ross. 2004. IT Governance: How Top Performance Manage TI Decision Rights For Superior Result. Havard School Press.

[11] Alvin, Wongso. 2013. Analisis dan Evaluasi Tata Kelola IT pada PT.FIF dengan standar COBIT 5. Skripsi Departemen Sistem Informasi Binus University 